\title{
Determination of the most common morphological patterns of anemia among Saudi anemic patients attending King Abdul-aziz Medical City-Riyadh
}

\section{Mohieldin Elsayid', Abdullah Mesfer Al-Qahtani', Abdullah Alanazi ${ }^{2}$, Shoeb Qureshi ${ }^{3}$}

Departments of ${ }^{1}$ Clinical Laboratory Sciences, ${ }^{2}$ Emergency Medical Services, ${ }^{3}$ Research Methodology, College of Applied Medical Sciences, King Saud Bin Abdul-Aziz University for Health Sciences, Riyadh, Saudi Arabia

Address for the Correspondence: Dr. Shoeb Qureshi, College of Applied Medical Sciences, King Saud Bin Abdul-aziz University, National Guards, P.O. Box 70819,

Riyadh 11577, Saudi Arabia.

E-mail: qsab2002@yahoo.co.in

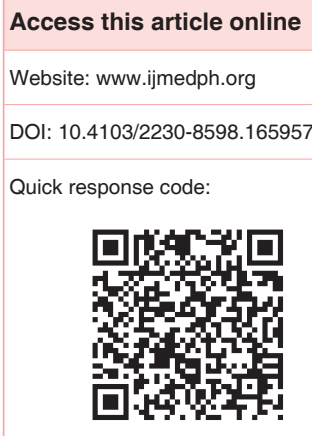

Background: Anemia is a medical condition in which the red blood cells (RBCs) count and hemoglobin $(\mathrm{Hb})$ are less than the normal range. The main causes of anemia are a decrease in RBCs, their destruction and decrease of $\mathrm{Hb}$ synthesis. A useful method for diagnosis and classification of anemias is based on the morphological appearance of RBCs on an ideal stained blood smear. The main terms used in such classification are normocytic normochromic, microcytic hypochromic and macrocytic anemia. Aim: The aim of this study is to determine the most common morphological pattern of anemia in Saudi anemic patients who were admitted at King Abdul-aziz Medical City-Riyadh. Materials and Methods: Retrospectively we evaluated the results of complete blood count $(C B C)$ and peripheral blood picture (PBP) of all anemic patients attending during the year 2013 (from $1^{\text {st }}$ January to $31^{\text {st }}$ December). Results: Participants in this study included 150 patients (13 infants, 27 children, 12 youths, 52 adults and 46 old). The gender distribution showed 70 males and 80 females. The results of CBC and PBP showed that 113 $(75.3 \%), 36(24 \%)$ and $1(0.7 \%)$ of the patients had normocytic normochromic, microcytic hypochromic and macrocytic pattern of anemia respectively. Conclusion: The normocytic normochromic pattern of anemia is highly frequent among this sample of Saudi patients while the macrocytic pattern of anemia is the lowest. According to gender groups microcytic hypochromic pattern of anemia is more common among females; malnutrition, increase of blood loss due to pregnancy or menstruation, and lack of iron absorption are the main causes, while the normocytic normochromic is highly frequent among males, which are mainly due to blood loss or chronic diseases.

Key words: Anemia, hypochromic, macrocytic, microcytic, morphological patterns, normochromic, normocytic

\section{INTRODUCTION}

Anemia is a medical condition in which the hemoglobin $(\mathrm{Hb})$ concentration and red blood cells (RBCs) count are lower than the normal range. The normal range of $\mathrm{Hb}$ and RBCs in general vary between males and females, it is defined as a Hb level of $<13.5 \mathrm{~g} / \mathrm{dl}$ and $<12.0 \mathrm{~g} / \mathrm{dl}$ in adult males and females respectively. The main causes of anemia are a decrease in RBCs, insufficient Hb synthesis or increased RBCs destruction, and the primary cause is an iron deficiency. ${ }^{[1]}$

This is an open access article distributed under the terms of the Creative Commons AttributionNonCommercial-ShareAlike 3.0 License, which allows others to remix, tweak, and build upon the work non-commercially, as long as the author is credited and the new creations are licensed under the identical terms.

For reprints contact: reprints@medknow.com

How to cite this article: Elsayid M, Al-Qahtani AM, Alanazi A, Qureshi S. Determination of the most common morphological patterns of anemia among Saudi anemic patients attending King Abdul-aziz Medical City-Riyadh. Int J Med Public Health 2015;5:301-4. 
Anemia is the most common health issue in the world, and it affects a large population in almost all countries. The most frequent etiologies of anemia are nutritional deficiencies, malaria, parasitic infections, blood loss, bone marrow replacement, or suppression and hemoglobinopathies. ${ }^{[2,3]}$ Arbitrarily, anemia may be classified as either moderate $(7.0-10.0 \mathrm{~g} / \mathrm{dl})$ or severe $(<7.0 \mathrm{~g} / \mathrm{dl}) .{ }^{[4]}$ The signs and symptoms of anemia are generally nonspecific, such as fatigue and weakness; it is often associated with gastrointestinal symptoms such as nausea, constipation, or diarrhea. ${ }^{[5,6]}$

Normocytic hypochromic red cells have the central area of polar occupying about a third of the cell diameter and show reduced staining, with an increase in the central area of the pallor. ${ }^{[7]}$ The morphological classification of anemia is based on morphological criteria of red cells in ideal thin blood film, and also on red cells indices, mean corpuscular volume (MCV), mean cell hemoglobin $(\mathrm{MCH})$ and $\mathrm{MCH}$ concentration $(\mathrm{MCHC}){ }^{[8]}$

This study is conducted to determine the most common morphological patterns of anemia among the Saudi anemic population, and this will give a good indication about the main cause of anemia among such patients, besides formulating a good protocol for diagnosis.

\section{MATERIALS AND METHODS}

\section{Study area}

The raw data of this study were collected from hematology laboratory in King Abdul-aziz Medical City (KAMC) at National Guard of Health Affairs hospital (NGHA) complex in Riyadh, Saudi Arabia.

\section{Study subjects Inclusion criteria}

Anemic patients (both the sexes) of all age groups, attending KAMC, Riyadh between $1^{\text {st }}$ January 2013 and 31 $1^{\text {st }}$ December 2013, were included in this study.

\section{Exclusion criteria}

Nonanemic patients were excluded.

\section{Study design}

This is a retrospective chart review study conducted to determine the morphological patterns of anemia among anemic patients at KAMC, Riyadh in the year 2013. This was compared with the international reference values.

\section{Sample size}

A total of 150 anemic patients were enrolled in this study.

\section{Sampling technique}

The results of complete blood count $(\mathrm{CBC})$ and peripheral blood picture (PBP) were collected from the medical report center in NGHA hospital using patient's medical record number.

\section{Data collection methods, instruments used, measurements}

A computer printout of demographic data and discharge clinical events/outcomes collected from records department for all episodes of hospital discharges that are coded for diagnosis of anemia between January and December 2013.

\section{Data analysis}

Study variables were incorporated on the excel sheet. The excel data were uploaded into SPSS software version 20 (The International Business Machines Corporation, New York) to determine the morphological patterns of anemia and their frequencies. A backup soft copy version, as well as a hard copy print, was dated, saved and secured after each data entry update.

\section{RESULTS}

The results of CBC and PBP showed that 113 (75.3\%), 36 (24\%), and $1(0.7 \%)$ of the patients had normocytic normochromic, microcytic hypochromic and macrocytic pattern of anemia respectively [Table 1 and Figure 1]. The gender wise classification of the patterns revealed that $62(55 \%)$ of male patients had normocytic normochromic patterns, while 51 (45\%) female patients and $7(19 \%)$ males patients had microcytic hypochromic patterns while in females patients is $29(81 \%)$ and one case of macrocytic pattern showed in males patients [Table 2].

The results of the mean of $\mathrm{Hb}$, hematocrit and RBCs count in anemic patients were $(8.6 \mathrm{~g} / \mathrm{dl}),(26.4 \%)$ and $\left(3.2 \times 10^{12}\right)$ respectively, which were significantly lower than the means of the control group $(P<0.05)$ [Table 3].

RBCs indices $\mathrm{MCV}, \mathrm{MCH}$ and $\mathrm{MCHC}$ in the patients with microcytic hypochromic PBP were significantly lower than the mean of the control group $(P<0.05)$ [Table 3].

\section{DISCUSSION}

The classification of anemia is based on three categories, including $\mathrm{RBC}$ morphology, pathogenicity of anemia and clinical presentation

\begin{tabular}{|c|c|}
\hline Morphological patterns of anemia & Frequency (\%) \\
\hline Normocytic normochromic & $113(75.3)$ \\
\hline Microcytic hypochromic & $36(24.0)$ \\
\hline Macrocytic anemia & $1(0.7)$ \\
\hline Total & $150(100)$ \\
\hline
\end{tabular}

\begin{tabular}{lccc} 
Table 2: The frequency of morphological patterns \\
among study participants to gender groups & \\
\cline { 2 - 3 } $\begin{array}{l}\text { Morphological patterns } \\
\text { of anemia }\end{array}$ & \multicolumn{2}{c}{ Gender } & Total \\
\cline { 2 - 3 } Male & Female & \\
\hline Normocytic normochromic & 62 & 51 & 113 \\
Microcytic hypochromic & 7 & 29 & 36 \\
Macrocytic anemia & 1 & 0 & 1 \\
Total & 70 & 80 & 150 \\
\hline
\end{tabular}




\begin{tabular}{|c|c|c|c|c|c|}
\hline Variables & Minimum & Maximum & Mean & SD & Normal range \\
\hline $\mathrm{Hb} \mathrm{g/dl}$ & 6.00 & 10.00 & 8.6 & 1.17393 & $\begin{array}{l}\text { Male: } 13.5-17.5 \mathrm{~g} / \mathrm{dl} \\
\text { Female: } 12.0-15.5 \mathrm{~g} / \mathrm{dl}\end{array}$ \\
\hline PCV percentage & 17.00 & 32.00 & 26.4 & 3.58299 & $\begin{array}{l}\text { Male: } 38.8-50.0 \% \\
\text { Female: } 34.9-44.5 \%\end{array}$ \\
\hline RBCs count c/cumm & 2.00 & 4.00 & 3.2 & 0.59907 & $\begin{array}{l}\text { Male: } 4.32-5.72 \times 10^{3} \mathrm{c} / \text { cumm } \\
\text { Female: } 3.90-5.03 \times 10^{3} \mathrm{c} / \text { cumm }\end{array}$ \\
\hline
\end{tabular}

$P<0.05$. RBCs = Red blood cells, $\mathrm{PCV}=$ Packed cell volume, SD = Standard deviation

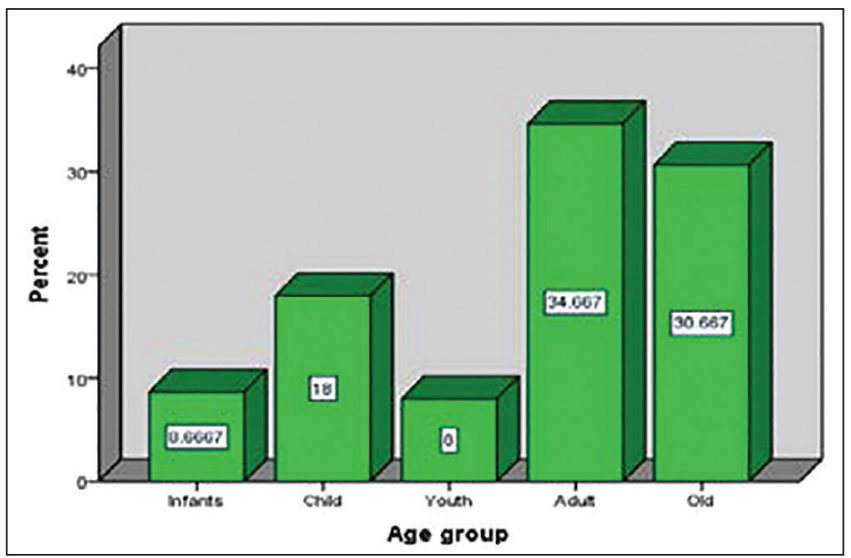

Figure 1: Distribution of age group among study participants

of anemia. These categories are very important in the classification and diagnosis of anemia..$^{[9]}$

In clinical practice, the morphological classification of anemia is based on red cell indices; $\mathrm{MCV}, \mathrm{MCH}$, and MCHC. ${ }^{[9]}$

The age group distribution of participants was 13, 27, 12, 52, and 46 infants, children, youth, adult and old respectively. The study revealed that the mean of $\mathrm{Hb}$, hematocrit and RBCs count in anemic patients were $8.6 \mathrm{~g} / \mathrm{dl}, 26.4 \%$ and $3.2 \times 10^{12}$ respectively, which was significantly lower. These findings are in agreement with those of El Kishawi et al. ${ }^{[10]}$ furthermore, the authors found conducted a research to assess the factors related to anemia and the determination of morphological patterns of anemia among children in association with malnutrition. Furthermore, the authors found significantly lower values of $\mathrm{MCV}, \mathrm{MCH}$, and MCHC RBCs indices in the study group of patients with microcytic hypochromic PBP were significantly lower.

The main causes of microcytic hypochromic anemia are shown to be iron deficiency anemia (IDA), thalassemia and anemia of chronic diseases. ${ }^{[11]}$ The main cause of microcytic hypochromic anemia is an iron deficiency. The confirmation or exclusion of IDA depends on estimation of the level of serum ferritin. ${ }^{[1]]}$ In developed countries, IDA occurs more frequently in adult men and in postmenopausal women. ${ }^{[12,13]}$

Our study showed that the normocytic normochromic pattern of anemia was more frequent than the macrocytic pattern. The gender wise classification of the patterns revealed a microcytic hypochromic pattern of anemia was more common among females. Malnutrition, an increase of blood loss due to pregnancy or menstruation, and lack of iron absorption are the main causes. In male patients, the frequency of the normocytic normochromic pattern of anemia was high, which may be mainly due to blood loss or chronic diseases. ${ }^{[14]}$ In normocytic anemia, the important issue is to identify the main cause and to prescribe the right treatment. The etiologies of normocytic normochromic anemia are nutritional, renal diseases (e.g., renal failure) and increased red cell destruction. ${ }^{[14]}$ In macrocytic anemia, the main causes are a low level of Vitamin B12 and a low level of erythrocyte folate. The estimation of both patterns of anemia will guide the proper diagnosis of macrocytic anemia. The most common cause of folate deficiency is either nutritional or malabsorption of this vitamin. In contrast, the deficiency of Vitamin B12 is almost resulting from malabsorption. ${ }^{[15,16]}$ The normocytic normochromic pattern of anemia is highly frequent among a study sample of the Saudi population while the macrocytic pattern was the lowest. The gender wise classification showed, the microcytic hypochromic pattern of anemia is more common among females while the normocytic normochromic pattern was found to be highly prevalent among males.

\section{RECOMMENDATIONS}

1. In order to get more informative data about the types of anemia, iron profile, serum B12 and serum folate should be done as routine hospital diagnostic protocol, in order to obtain the causative factors of microcytic hypochromic, normocytic normochromic, and macrocytic patterns among Saudi populations.

2. Special care should be taken by primary health care provider to detect and prevent anemia, especially among children and women.

\section{Financial support and sponsorship}

Nil.

\section{Conflicts of interest}

There are no conflicts of interest.

\section{REFERENCES}

1. Veng-Pedersen P, Chapel S, Schmidt RL, Al-Huniti NH, Cook RT, Widness JA. An integrated pharmacodynamic analysis of erythropoietin, 
reticulocyte, and hemoglobin responses in acute anemia. Pharm Res 2002;19:1630-5.

2. Gruchy GC. Clinical Hematology in Medical Practice, by Penington D, Rush B, Castaldi P. Delhi, India: CBS Publisher, Taj Press; 1987.

3. Hoffbrand AV. Erythropoiesis and general aspects of anemia. In: Hoffbrand AV, Pettit JE, editors. Essential Haematology. $3^{\text {rd }}$ ed. Oxford: Blackwell Scientific; 1993. p. 12-35.

4. Reiss RF. Laboratory diagnosis of erythroid disorders. In: Tilton RC, Balows A, Hohnadel DC, Reiss RF, editors. Clinical Laboratory Medicine. St. Louis: Mosby-Year Book; 1992. p. 898-937.

5. Lindenbaum J. An approach to the anemias. In: Wyngaarden JB, editor. Cecil Textbook of Medicine. $19^{\text {th }}$ ed., Vol. 1. Philadelphia: WB Saunders; 1992. p. 822-31.

6. Hoffbrand AV, Lewis SM, Tuddenham EG. Essential Hematology. $5^{\text {th }}$ ed. London, England: Dacie and Lewis, Oxford, Blackwell; 2004.

7. Hoggbrand AV, Catorsky D, Tuddenham EG. Postgraduate Hematology. $5^{\text {th }}$ ed. Oxford: Blackwell; 2005.

8. Anía Lafuente BJ, Fernández-Burriel Tercero M, Suárez Almenara JL, Betancort Mastrángelo CC, Guerra Hernández L. Anemia and functional incapacity at admission to a geriatric home. An Med Interna 2001;18:9-12.
9. Vives Corrons JL. La anemia, aspectos enerals del diagnóstico. In Sans-Sabrafen J, Besses Raebel C, Vives Corrons JL, et al., editors. Hematología Clínica. $5^{\text {th }}$ ed. Madrid: Elsevier Spain; 2006. p. 107-26.

10. El Kishawi RR, Soo KL, Abed YA, Wan Muda WA. Anemia among children aged 2-5 years in the Gaza Strip- Palestinian: A cross-sectional study. BMC Public Health 2015;15:319.

11. Guyatt $\mathrm{GH}$, Oxman AD, Ali M, Willan A, Mcllroy W, Patterson C Laboratory diagnosis of iron-deficiency anemia: An overview. J Gen Intern Med 1992;7:145-53.

12. Calvey HD, Castleden CM. Gastrointestinal investigations for anaemia in the elderly: A prospective study. Age Ageing 1987;16:399-404.

13. Sayer JM, Long RG. A perspective on iron deficiency anaemia. Gut 1993;34:1297-9.

14. Tefferi A. Anemia in adults: A contemporary approach to diagnosis. Mayo Clin Proc 2003;78:1274-80.

15. Colon-Otero G, Menke D, Hook CC. A practical approach to the differential diagnosis and evaluation of the adult patient with macrocytic anemia. Med Clin North Am 1992;76:581-97.

16. Hernández Nieto L, Hernández García MT, Pintado Cros T, Juncá Piera J, Vives Corrons JL, Martín Vega C. Medicina Interna. C Rozman (Dir). $15^{\text {th }}$ ed. Madrid: Elsevier; 2004. p. 1644-69. 